\title{
Interactions Between the Pathogenic Bacterium Vibrio parahaemolyticus and Red-tide Dinoflagellates
}

\author{
Kyeong Ah Seong ${ }^{1 *}$ and Hae Jin Jeong ${ }^{2}$ \\ ${ }^{1}$ Saemankeum Environmental Research Center, Kunsan National University, Kunsan 573-701, Korea \\ ${ }^{2}$ School of Earth and Environmental Sciences, College of Natural Sciences, Seoul National University, Seoul 151-747, Korea
}

Received 29 May 2011; Revised 8 June 2011; Accepted 21 June 2011

(C) KSO, KORDI and Springer 2011

\begin{abstract}
Vibrio parahaemolyticus is a common pathogenic bacterium in marine and estuarine waters. To investigate interactions between $V$. parahaemolyticus and co-occurring redtide dinoflagellates, we monitored the daily abundance of 5 common red tide dinoflagellates in laboratory culture; Amphidinium carterae, Cochlodinium ploykrikoides, Gymnodinium impudicum, Prorocentrum micans, and P. minimum. Additionally, we measured the ingestion rate of each dinoflagellate on $V$. parahaemolyticus as a function of prey concentration. Each of the dinoflagellates responded differently to the abundance of $V$. parahaemolyticus. The abundances of $A$. carterae and $P$. micans were not lowered by $V$. parahaemolyticus, whereas that of $C$. polykrikodes was lowered considerably. The harmful effect depended on bacterial concentration and incubation time. Most C. polykrikoides cells died after 1 hour incubation when the $V$. parahaemolyticus concentration was $1.4 \times 10^{7}$ cells $\mathrm{ml}^{-1}$, while cells died within 2 days of incubation when the bacterial concentration was $1.5 \times 10^{6}$ cells $\mathrm{ml}^{-1}$. With increasing $V$. parahaemolyticus concentration, ingestion rates of $P$. micans, $P$. minimum, and $A$. carterae on the prey increased, whereas that on $C$. polykrikoides decreased. The maximum or highest ingestion rates of $P$. micans, $P$. minimum, and A. carterae on $V$. parahaemolyticus were 55,5 , and 2 cells alga ${ }^{-1} \mathrm{~h}^{-1}$, respectively. The results of the present study suggest that $V$. parahaemolyticus can be both the killer and prey for some red tide dinoflagellates.
\end{abstract}

Key words - algicidal bacteria, feeding, harmful algal bloom, ingestion, red tide

\section{Introduction}

Bacteria and red-tide dinoflagellates are major components of marine ecosystems (Azam 1998; Doucette et al. 1998).

*Corresponding author. E-mail: scaway@kunsan.ac.kr
They usually co-occur, thus most studies have investigated their joint interactions (Lee 1990; Doucette et al. 1999; Mayali and Azam, 2004). Some bacteria are known to kill red tide dinoflagellates such as algicidal bacteria (Kitaguchi et al. 2001; Amaro et al. 2005). A number of algicidal bacteria have been reported since the 1990s (Imai et al. 1993, 2001; Doucette et al. 1998; Park et al. 1998; Kim et al. 1999; Byun et al. 2002; Mayali and Azam 2004; Imai and Kimura 2008). Lysis of algae by algicidal bacteria is known to play an important role in terminating red tides (Skerratt et al. 2002). On the contrary, bacteria have been revealed to be eaten by red-tide dinoflagellates (Nygaard and Tobiesen, 1993; Seong et al. 2006). Additionally, some bacteria are known to live inside red tide dinoflagellates in a symbiotic relationship (Green et al. 2004; Hackett et al. 2004; Jasti et al. 2005). Thus, interactions between bacteria and red tide dinoflagella can be complicated.

Vibrio parahaemolyticus is a common pathogenic bacterium in marine and estuarine waters (Hervio-Heath et al. 2002; Makino et al. 2003; Yeung and Boor 2004). This bacterium, when ingested, causes watery diarrhea often with abdominal cramping, nausea, vomiting, fever, and chills (Dadisman et al. 1972). V. parahaemolyticus can also cause an infection of the skin when an open wound is exposed to warm seawater (Wright et al. 2009). V.parahaemolyticus is sometimes abundant during red tides dominated by dinoflagellates (Romalde et al. 1990; Eiler et al. 2006). However, there are very few studies on interactions between $V$. parahaemolyticus and red-tide dinoflagellates (Bienfang et al. 2011), which makes the exploration of this topic worthwhile.

We isolated and established a clonal culture of $V$. 
parahaemolyticus from seawater to investigate interactions between $V$. parahaemolyticus and co-occurring red-tide dinoflagellates. In particular, we monitored the abundance of 5 common red tide dinoflagellates and measured the growth and ingestion rates of the dinoflagellates on $V$. parahaemolyticus as a function of the prey concentration on the daily basis. The results of the present study provide a basis for understanding interactions between $V$. parahaemolyticus and red tide dinoflagellates and dynamics of these two components in marine ecosystems.

\section{Materials and Methods}

\section{Preparation of experimental organisms}

Red-tide dinoflagellates were grown at $20^{\circ} \mathrm{C}$ in enriched $\mathrm{f} / 2$ seawater media (Guillard and Ryther, 1962) without silicate under a $14 \mathrm{~h}$ light:10h dark cycle of $30 \mu \mathrm{E} \mathrm{m}^{-2} \mathrm{~s}^{-1}$. The mean equivalent spherical diameter $(\mathrm{ESD}) \pm$ standard deviation was measured by an electronic particle counter (Coulter Multisizer II, Coulter Corporation, Miami, Florida, USA) (Table 1).

For isolation of Vibrio parahaemolyticus, water samples were collected from surface waters of Shiwha Bay, Korea, in September 2005. Samples were immediately transferred to the laboratory with a temperature of below $4{ }^{\circ} \mathrm{C}$. Subsequently, $0.2 \mathrm{ml}$ of each diluted sample was inoculated on to Marine agar plate (Difco 2216, Franklin lakes, NJ).
Samples in the plate were incubated at $37^{\circ} \mathrm{C}$ for a week under dark condition. To isolate the colony separately, each colony was streaked on the new plate. Again, each colony was isolated and transferred to $50 \mathrm{ml}$ of $\mathrm{Na}$ broth (Andersen et al. 1974). Isolated bacterial cultures were incubated until the stationary phase (approximately 2-3 d) on a shaker at $70 \mathrm{rpm}$ at $37^{\circ} \mathrm{C}$. V. parahaemolyticus was identified by analyzing the sequence of $16 \mathrm{~S}$ rDNA. Its sequence shows $99 \%$ similarity with species of $V$. parahaemolyticus.

\section{Harmful effects of Vibrio parahaemolyticus}

Experiment 1 was designed to assess whether dense culture or filtrate of $V$. parahaemolyticus is able to kill redtide dinoflagellates Amphidinium carterae, Cochlodinium polykrikoides, Gymnodinium impudicum, Prorocentrum micans, and $P$. minimum in laboratory culture.

A dense culture of the target dinoflagellate $(20,000$ 400,000 cells) was added to each well of 6 well plate chambers. A dense culture of $V$. parahaemolyticus (ca, $8 \times 10^{5}-8 \times 10^{8}$ cells) was added to each well of the chambers (Two final concentrations $=10^{6}$ and $10^{7}$ cells $\mathrm{ml}^{-1}$ ). Triplicate experimental wells for each $V$. parahaemolyticus final concentration (mixture of target dinoflagellate and $\mathrm{V}$. parahaemolyticus) and triplicate control wells (target dinoflagellate only) were set up. After 0.5, 1, 2, 4, and $6 \mathrm{~h}$ of incubation, swimming behaviors of target dinoflagellate cells in each well were examined under an inverted light

Table 1. Dinoflagellate species used as predators on and/or victims by target algicidal bacteria. Mean equivalent spherical diameter $(\mathrm{ESD}, \mu \mathrm{m})( \pm$ Standard deviation) was measured by an electronic particle counter measured before these experiment; $\mathrm{n}>2000$ for each species. MIR: Maximum ingestion rate of the dinoflagellates on Vibrio parahaemolyticus $\left(\mathrm{Vp}\right.$, cells alga $\left.{ }^{-1} \mathrm{~h}^{-1}\right)$. LCBKD: Lowest concentration of algicidal bacteria for killing the target dinoflagellate (in bacterial cells $\mathrm{ml}^{-1}$ ). NHE: No Harmful Effect

\begin{tabular}{|c|c|c|c|c|c|}
\hline Species & 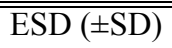 & "MIR & Target bacterium & LCBKD & References \\
\hline Amphidinium carterae & $6.6(1.5)$ & 1.2 & Vibrio parahaemolyticus & NHE & This study \\
\hline Amphidinium carterae & & & $\begin{array}{l}\text { Vibrio harveyi } \\
\text { V. alginolyticus } \\
\text { V. parahaemolyticus }\end{array}$ & NHE & Nayak et al. 2000 \\
\hline Prorocentrum minimum & $12.1(2.5)$ & 5.1 & V. parahaemolyticus & $1.4 \times 10^{7}$ & This study \\
\hline Prorocentrum minimum & & & Psedoalteromonas haloplanktis & $2.5 \times 10^{4}\left(\mathrm{cfu} \mathrm{ml}^{-1}\right)$ & Kim et al. 2009 \\
\hline Prorocentrum minimum & & & Shewanella IRI-160 & $\sim 10^{9}$ & Hare et al. 2005 \\
\hline Prorocentrum micans & $26.6(2.8)$ & 55 & V. parahaemolyticus & $1.4 \times 10^{7}$ & This study \\
\hline Prorocentrum micans & & & Psedomonas sp. LG-2 & $1.3 \times 10^{6}$ & Lee and Park, 1998 \\
\hline Gymnodinium impudicum & $17.8(2.6)$ & 1.6 & V. parahaemolyticus & $1.4 \times 10^{7}$ & This study \\
\hline Gymnodinium nagasakiense & & & Flavobacterium sp. & $>10^{6}$ & Fukami et al. 1992 \\
\hline Cochlodinium polykrikoides & $25.9(2.9)$ & ND & V. parahaemolyticus & $8.8 \times 10^{5}$ & This study \\
\hline Cochlodinium polykrikoides & $25.9(2.9)$ & ND & $\begin{array}{l}\text { Alteromonas } \mathrm{sp} . \\
\text { Psedoalteromonas } \mathrm{sp}\end{array}$ & $<10^{5} \sim 10^{7}$ & Imai and Kimura 2008 \\
\hline Cochlodinium polykrikoides & $25.9(2.9)$ & ND & Alteromonas sp. & $9.0 \times 10^{5}$ & Lee et al. 2008 \\
\hline
\end{tabular}


microscope.

To test the harmful effects of the filtrate from $V$. parahaemolyticus culture on each dinoflagellate, dense cultures $\left(10^{6}\right.$ and $10^{7}$ cells $\left.\mathrm{ml}^{-1}\right)$ of exponentially growing $V$. parahaemolyticus were transferred to centrifuge tubes. After 20 min of centrifugation at 20,000 g, the supernatant (suspended aliquot) was filtered through a $0.2 \mu \mathrm{m}$ poresized filter (Whatmann, Polycarbonate, Maidstone, UK) to remove bacteria cells. Filtered supernatants (0.01-0.1 ml $\left.\mathrm{ml}^{-1}\right)$ were transferred into each of the triplicate wells containing the target dinoflagellate. Additionally, triplicate control wells (target dinoflagellate only without added filtrate) were set up. After 0.5, 1, 2, 4, and 6 h of incubation, swimming behaviors of target dinoflagellate cells were examined as described above.

\section{Numerical response by dinoflagellates to Vibrio con- centration}

Experiment 2 was designed to investigate numerical responses by red-tide dinoflagellates Amphidinium carterae, Cochlodinium polykrikoides, Gymnodinium impudicum, $P$. minimum, and Prorocentrum micans to the concentration of $V$. parahaemolyticus as a function of elapsed incubation time.

Dense cultures of each red tide alga $(80,000-1,600,000$ cells) and/or $V$. parahaemolyticus (ca, $8 \times 10^{5}-8 \times 10^{8}$ cells) were transferred to $80 \mathrm{ml}$ PC bottles. Triplicate experimental bottles (mixture of target dinoflagellate and $V$. parahaemolyticus) and triplicate control bottles (target dinoflagellate only) were established at each $V$. parahaemolyticus concentration. The initial concentrations of $V$. parahaemolyticus were $1 \times 10^{4}, 1 \times 10^{5}, 8 \times 10^{5}, 1 \times 10^{6}, 1 \times 10^{7}$ cells $\mathrm{ml}^{-1}$. The bottles were filled to capacity with freshly filtered seawater, and then placed on the shelf $\left(30 \mu \mathrm{E} \mathrm{m}^{-2} \mathrm{~s}^{-1}\right)$. From day 0 to day 6 , a $4 \mathrm{ml}$ aliquot was removed from each bottle everyday and fixed with 5\% Lugol's solution, while another $4 \mathrm{ml}$ aliquot were fixed with $4 \%$ formalin. All or $>300$ predator cells, fixed in Lugol's solution, in three $1 \mathrm{ml}$ SedqwickRafter counting chambers were enumerated. The aliquots fixed with formalin were filtered onto $0.2 \mu \mathrm{m}$ pore sized, 25 $\mathrm{mm}$ PC black membrane filters and then the concentrated cells on the membranes were observed under an epifluorescence microscope (Olympus BX51) with UV-light excitation at a magnification of $1000 \mathrm{x}$ to determine the concentration of bacteria stained using 4'6'-diamidino-2-phenylindole (DAPI. final con.:1 $\mu \mathrm{M}$ ).

The specific growth rate of target dinoflagellate, $\mu\left(\mathrm{d}^{-1}\right)$, was calculated by averaging the growth rates obtained at each interval as follows:

$$
\mu=\left[\operatorname{Ln}\left(\mathrm{G}_{\mathrm{t}} / \mathrm{G}_{0}\right)\right]
$$

Where $G_{0}$ is the initial concentration of the dinoflagellate at the beginning of each day and $G_{t}$ is the final concentration at the end of the day. The first and last days in this calculation were Day 2 and Day 5, respectively.

\section{Ingestion rate of dinoflagellates on Vibrio}

Experiment 3 was designed to measure the ingestion rates of Amphidinium carterae, Cochlodinium polykrikoides, Gymnodinium impudicum, Prorocentrum micans, and $P$. minimum on $V$. parahaemolyticus as a function of the prey concentration.

One or two days before this experiment, V.parahaemolyticus cells collected from centrifugation were fluorescently labeled using the method of Sherr et al. (1987), and the fluorescently labeled bacteria (FLB) were added to triplicate $80 \mathrm{ml}$ PC experimental bottles containing mixtures of $V$. parahaemolyticus $\left(1 \times 10^{6}-2 \times 10^{9}\right.$ cells $)$ and target dinoflagellate (80,000-1,600,000 cells). The abundance of the FLB was $30 \%$ of total bacteria. Triplicate control bottles containing only target dinoflagellate were also established. All bottles were filled to capacity with freshly filtered and autoclaved seawater, capped, placed on a shelf and incubated at $20^{\circ} \mathrm{C}$ under continuous illumination of $30 \mu \mathrm{E} \mathrm{m}^{-2} \mathrm{~s}^{-1}$ of cool white fluorescent light. After 1, 5, 10, 20, and $30 \mathrm{~min}$ incubation periods, $8 \mathrm{ml}$ aliquots were removed from each bottle, transferred $20 \mathrm{ml}$ vials, and then fixed with borate-buffered formalin (final concentration=3\%). The fixed samples were stained using 4'6'-diamidino-2-phenylindole (DAPI. final con.: $1 \mu \mathrm{M}$ ), and then filtered onto $3 \mu \mathrm{m}$ pore size PC white-membrane filters. The FLB inside a dinoflagellate cell were enumerated under an epifluorescence microscope with blue light excitation. Bacteria (both FLB and non FLB) outside dinoflagellates were also enumerated under an epifluorescence microscope with UV light excitation for non-FLB and blue light excitation for FLB. After subsampling, the bottles were capped, placed on a shelf, and incubated again, as described above. Each value of the ingestion rate (cells alga ${ }^{-1} \mathrm{~h}^{-1}$ ) was obtained. The relationship of ingestion rates to prey abundance was fitted to a Michaelis-Menten equation:

$$
\mathrm{IR}=\mathrm{I}_{\max }(\mathrm{x}) /\left[\mathrm{K}_{\mathrm{IR}}+(\mathrm{x})\right]
$$


Where $I_{\max }$ is the maximum ingestion rate (cells alga $\left.{ }^{-1} \mathrm{~h}^{-1}\right) ; x$ the prey concentration (cells $\mathrm{ml}^{-1}$ ), and $K_{\mathrm{IR}}$ the prey concentration sustaining $1 / 2 I_{\max }$. The prey concentration is the sum of living bacteria and FLBs.

A feeding experiment of $C$. polikrikoides on $V$. parahaemolyticus was also performed for $30 \mathrm{~min}$. However, $C$. polikrikoides was killed within $30 \mathrm{~min}$ in high density of $V$. parahaemolyticus during this experiment. Thus, we could not measure the ingestion rate at the $V$. parahaemolyticus concentrations $>10^{5}$ cells ml ${ }^{-1}$.

Before these experiments were conducted, bacteria in the original dinoflagellate cultures were eliminated down to $1.4 \times 10^{4} \mathrm{cell} \mathrm{ml}^{-1}$ with a dilution method using filtered and autoclaved seawater.

\section{Results}

\section{Effects of $V$. parahaemolyticus concentration and incubation time}

The red tide dinoflagellates tested in the present study responded differently to a dense culture of $V$. parahaemolyticus or its filtrate. The body of $C$. polikrikoides was decomposed within $20 \mathrm{~min}$ after the addition of either dense $V$. parahaemolyticus culture $\left(1 \times 10^{7}{\left.\text { cells } \mathrm{ml}^{-1}\right)}^{-1}\right.$ or filtrate of the culture (Fig. 1). However, the shape of P. micans did not changed by either $V$. parahaemolyticus nor the filtrate (Fig. 2). The shape of P.minimum and A.carterae did not change likewise. Gymnoninium impudicum, having a similar shape with $C$. polykrikoides was decomposed after 1 hour.

The abundance of all dinoflagellates tested in the present study was affected by $V$. parahaemolyticus (Fig. 3-7). However, the degree of effectiveness (i.e. growth rate) was species-dependent. In addition, the concentrations of $V$. parahaemolyticus in which each of the red tide dinoflagellates was killed were also different among the species.
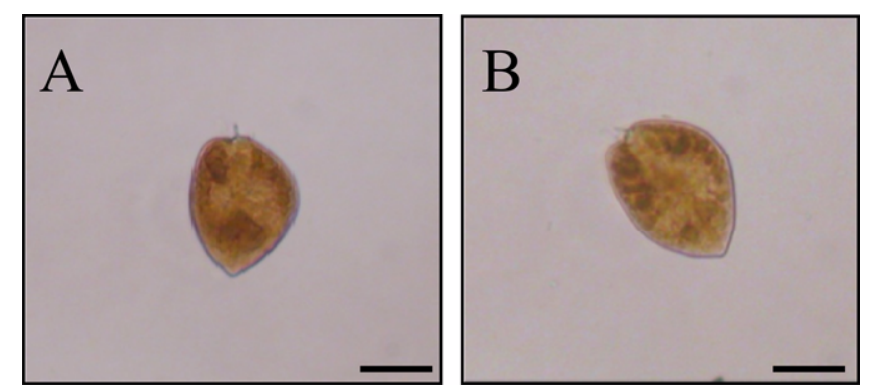

Fig. 2. The body shape of Prorocentrum micans cells at the beginning of the experiment (A) and 1 hour later after addition of $1 \times 10^{7}$ cells $\mathrm{ml}^{-1}$ Vibrio parahaemolyticus. Scale bar $=10 \mu \mathrm{m}$

With increasing incubation time, the abundances of $A$. carterae in control and at all $V$. parahaemolyticus concentrations increased (Fig. 3A). However, the growth rate of A. carterae at all $V$. parahaemolyticus concentrations provided here were not significantly different from that in the control ( $\mathrm{p}>0.1$, one-tailed $\mathrm{t}$ test; Fig. 3B). This evidence suggests that the growth of $A$. carterae may be not significantly affected by $V$. parahaemolyticus.

With increasing incubation time, the abundances of Prorocentrum minimum increased at all $V$. parahaemolyticus concentrations, except the control and the highest concentration (Fig. 4A). The growth rate of $P$. minimum at V. parahaemolyticus concentration of $8.8 \times 10^{5}$ cells ml ${ }^{-1}$ was significantly higher than that in the control $(\mathrm{p}<0.05$, onetailed t test). However, the growth rates of P. minimum at the other $V$. parahaemolyticus concentrations were not significantly different from that in the control $(\mathrm{p}>0.1$, one-tailed $\mathrm{t}$ test; Fig. 4B). This evidence suggests that the growth of $P$. minimum may only be stimulated by $V$. parahaemolyticus at concentrations of $8.8 \times 10^{5}$ cells ml $^{-1}$.

With increasing incubation time, the abundances of Prorocentrum micans increased in the control and at all $\mathrm{V}$.
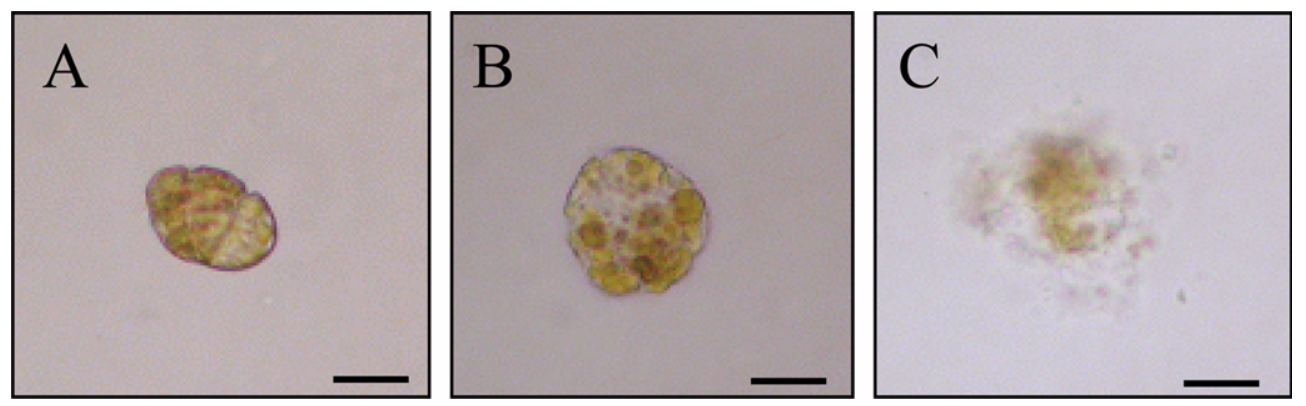

Fig. 1. The body shape of Cochlodinium polykrikoides cells at the beginning of the experiment (A) and 40 minute (B) and 1 hour later after addition of $1 \times 10^{7}$ cells $\mathrm{ml}^{-1}$ Vibrio parahaemolyticus. Scale bar $=10 \mu \mathrm{m}$ 

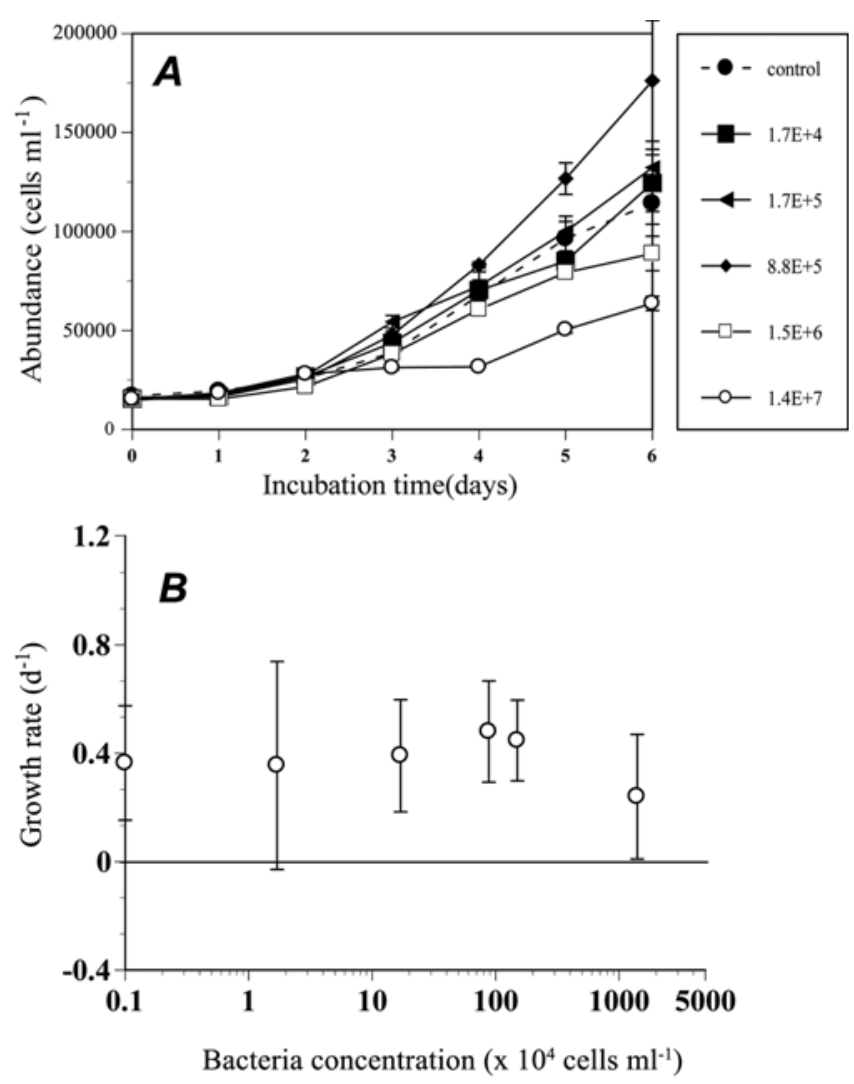

Fig. 3. The abundance (A) and growth rate (B) of Amphidinium carterae as functions of the abundance of Vibrio parahaemolyticus and elapsed incubation time. Legends represent the concentration of $V$. parahaemolyticus. Control: without V. parahaemolyticus. Symbols represent means \pm standard errors. See text for calculation of the growth rate

parahaemolyticus concentrations, except at the highest concentration, (Fig. 5A). The growth rates of P. micans at all $V$. parahaemolyticus concentrations were not significantly different from that in the control $(\mathrm{p}>0.1$, one-tailed $\mathrm{t}$ test; Fig. 5B). This evidence suggests that the growth of $P$. micans may be not affected by $V$. parahaemolyticus.

With increasing incubation time, the abundances of $G$. impudicum increased in the control and at the $V$. parahaemolyticus concentrations $\leq 1.5 \times 10^{6}$ cells $\mathrm{ml}^{-1}$, but decreased at the $V$. parahaemolyticus concentration of $1.4 \times 10^{7}$ cells mll $^{-1}$ (Fig. 6A). The growth rate of $G$. impudicum at the $V$. parahaemolyticus concentration of $1.4 \times 10^{7}$ was significantly lower than that in the control $(\mathrm{p}<0.05$, onetailed t test), while growth rates at the other V.parahaemolyticus concentrations were higher than in the control $(\mathrm{p}<0.05$, onetailed $t$ test; Fig. 6B). This evidence suggests that the growth of G. impudicum may be negatively affected by $V$.
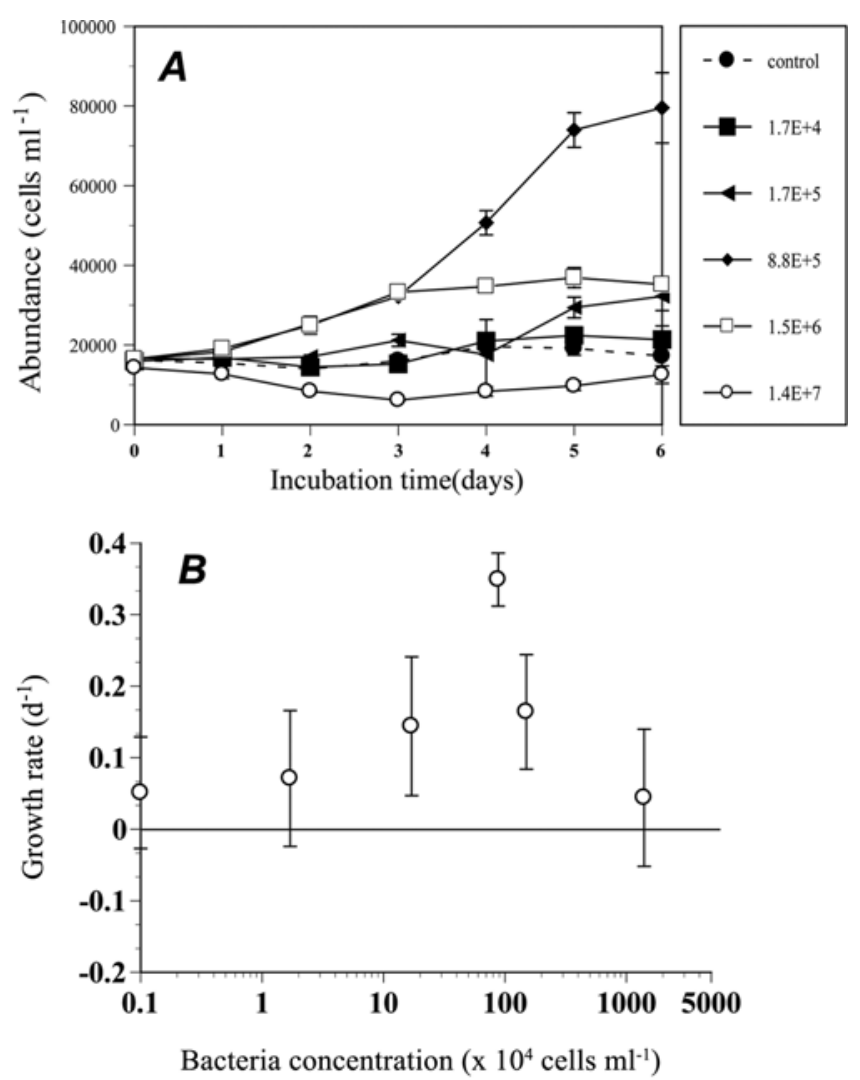

Fig. 4. The abundance (A) and growth rate (B) of Prorocentrum minimum as functions of the abundance of Vibrio parahaemolyticus and elapsed incubation time. Legends represent the concentration of $V$. parahaemolyticus. Control: without $V$. parahaemolyticus. Symbols represent means \pm standard errors. See text for calculation of the growth rate

parahaemolyticus at the concentration of $1.4 \times 10^{7} \mathrm{cells} \mathrm{ml}^{-1}$, but it may be positively affected at lower bacterial concentrations.

With increasing incubation time, the abundances of Cochlodinium polykrikoides in control and at the $V$. parahaemolyticus concentration of $1.7 \times 10^{4}-8.8 \times 10^{5}$ cells $\mathrm{ml}^{-1}$ did not markedly change, while those at the higher concentrations decreased (Fig. 7A). Most C. polykrikoides cells died after 1 day of incubation when the V.parahaemolyticus concentration was $1.4 \times 10^{7} \mathrm{cells} \mathrm{m}^{-1}$, while cells died within 2 days of incubation when the bacterial concentration was $1.5 \times 10^{6} \mathrm{cells}^{-1}$. The growth rates of C. polykrikoides at the $V$. parahaemolyticus concentration of $1.7 \times 10^{4}-8.8 \times 10^{5}$ cells $\mathrm{ml}^{-1}$ was not significantly different from that in the control ( $\mathrm{p}>0.1$, one-tailed $\mathrm{t}$ test; Fig. 7B). However, the growth rates of $C$. polykrikoides at the $V$. parahaemolyticus concentrations of $1.5 \times 10^{6}$ and $1.4 \times 10^{7}$ cells $\mathrm{ml}^{-1}$ were -0.6 

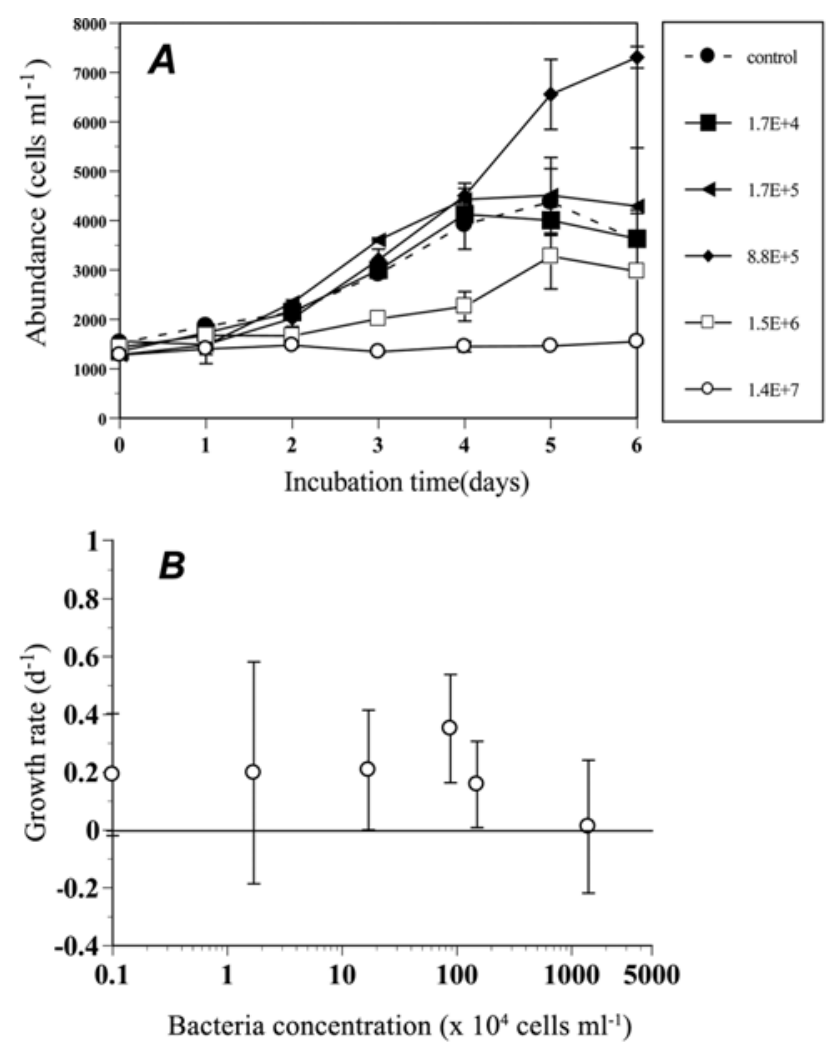

Fig. 5. The abundance (A) and growth rate (B) of Prorocentrum micans as functions of the abundance of Vibrio parahaemolyticus and elapsed incubation time. Legends represent the concentration of $V$. parahaemolyticus. Control: without $V$. parahaemolyticus. Symbols represent means \pm standard errors. See text for calculation of the growth rate

and $-1.0 \mathrm{~d}^{-1}$, respectively. This evidence suggests that the growth of C. polykrikoides may be negatively affected by $V$. parahaemolyticus at the bacterial concentrations $\geq 1.5 \times 10^{6}$ cells $\mathrm{ml}^{-1}$.

\section{Ingestion rates of dinoflagellates on $\boldsymbol{V}$. parahaemolyticus}

The functional response of each of the 5 red tide dinoflagellates to $V$. parahaemolyticus concentration was different from that of the other dinoflagellates (Fig. 8). With increasing $V$. parahaemolyticus concentration, the ingestion rates of $A$. carterae and $P$. minimum increased rapidly at prey concentrations of $<1-3 \times 10^{6}$ cells ml ${ }^{-1}$ and slowly at higher prey concentrations (Fig. $8 \mathrm{~A}, \mathrm{~B}$ ). When the data were fitted to Eq. (2), the maximum ingestion rates of $A$. carterae and P. minimum on $V$. parahaemolyticus were 1.2 and 5.1 cells alga ${ }^{-1} \mathrm{~h}^{-1}$, respectively. The maximum clearance rates of A. carterae and P. minimum on V.parahaemolyticus were 0.1 and $0.3 \mathrm{nl} \mathrm{alga}^{-1} \mathrm{~h}^{-1}$, respectively.

With prey concentrations of $<1.4 \times 10^{7}$ cells $\mathrm{ml}^{-1}$, the
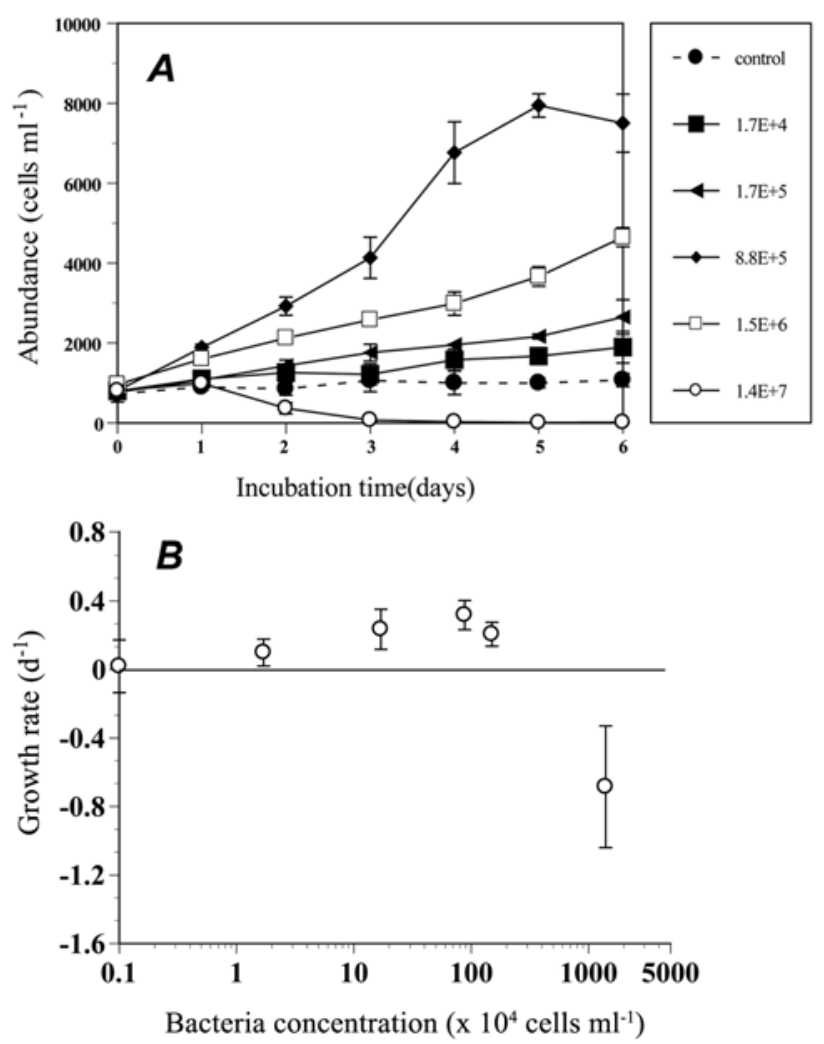

Fig. 6. The abundance (A) and growth rate (B) of Gymnodinium impudicum as functions of the abundance of Vibrio parahaemolyticus and elapsed incubation time. Legends represent the concentration of $V$. parahaemolyticus. Control: without $V$. parahaemolyticus. Symbols represent means \pm standard errors. See text for calculation of the growth rate

ingestion rate of $P$. micans on $V$. parahaemolyticus increased linearly (Fig. $8 \mathrm{C}$ ). The highest value among the ingestion rates was 55 cells alga $^{-1} \mathrm{~h}^{-1}$. The maximum clearance rate of P. micans on $V$. parahaemolyticus was $3.7 \mathrm{nl}$ algae $^{-1} \mathrm{~h}^{-1}$.

The ingestion rates of Gymnodinium impudicum on $V$. parahaemolyticus were between $1.5-2.5$ cells alga $^{-1} \mathrm{~h}^{-1}$ without any particular pattern (Fig. 8D).

With increasing prey concentrations, the ingestion rate of C. polykrikoides on V. parahaemolyticus decreased (Fig. 8E). The rate was not detected at prey concentrations of $<1.5 \times 10^{6}$ cells $\mathrm{ml}^{-1}$.

\section{Discussion}

\section{Vibrio parahaemolyticus as a killer}

The results of the present study show that the harmful pathogenic bacterium $V$. parahaemolyticus can be a killer and/or prey for red tide dinoflagellates. At $V$. parahaemolyticus concentrations of $\leq 1.5 \times 10^{6}$ cells ml $^{-1}, C$. polykrikoides is a 

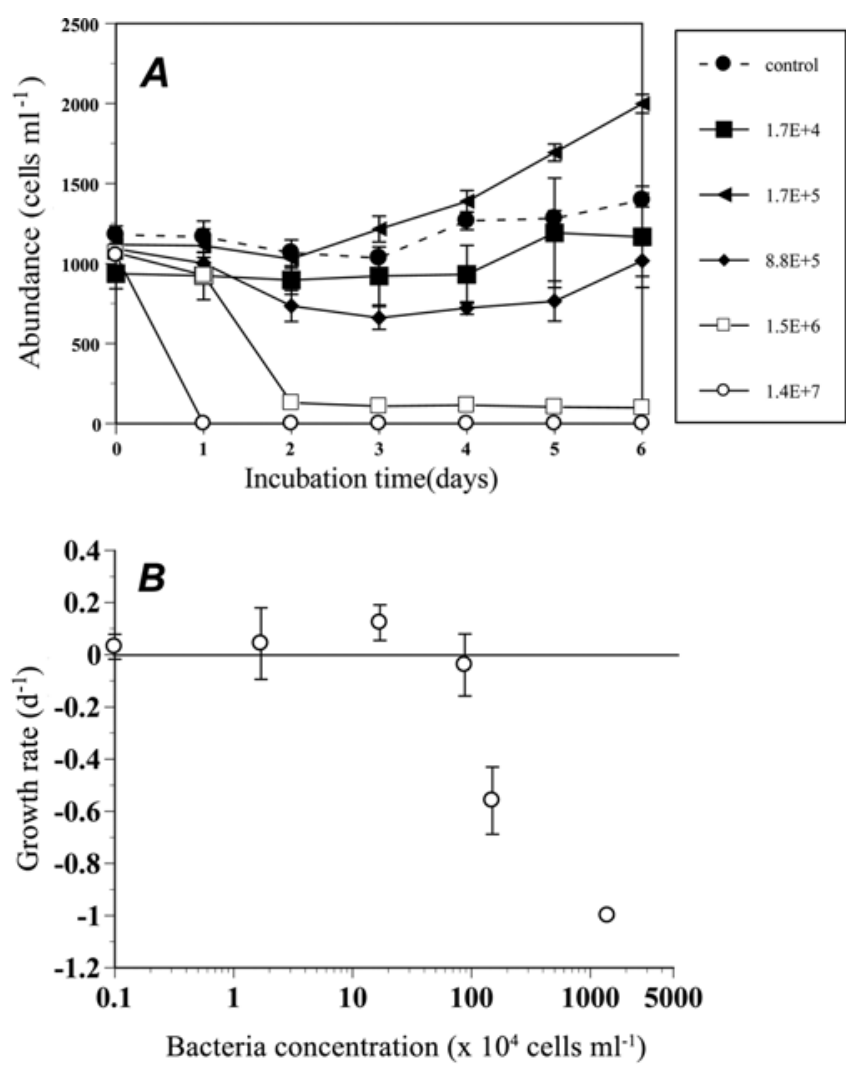

Fig. 7. The abundance (A) and growth rate (B) of Cochlodinium polykrikoides as functions of the abundance of Vibrio parahaemolyticus and elapsed incubation time. Legends represent the concentration of $V$. parahaemolyticus. Control: without V. parahaemolyticus. Symbols represent means \pm standard errors. See text for calculation of the growth rate

victim of $V$. parahaemolyticus. Additionally, at the $V$. parahaemolyticus concentration of $1.4 \times 10^{7}$ cells $\mathrm{ml}^{-1}$, G.impudicum was also a victim. However, A.carterae, $P$. minimum, and $P$. micans are mainly grazers on $V$. parahaemolyticus at $V$. parahaemolyticus concentrations of $\leq 1.5 \times 10^{6}$ cells ml $^{-1}$, while they could be victims as well as grazers at the higher $V$. parahaemolyticus concentrations. Nayak et al. (2000) reported that the concentrations of Vibrio harveyi, V. alginolyticus, and V. parahaemolyticus, which was incubated with $A$. carterae, gradually decreased. A. carterae was likely to feed on these Vibrios, even though the authors did not mention this possibility.

Algicidal bacteria have been known to kill algae or inhibit their growth through direct contact with algal cells (Manage et al. 2000; Furusawa et al. 2003), or indirectly through release of toxic compounds into the ambient environment (Holmstrom and Kjelleberg, 1999; Nakashima et al. 2006). Psedomonas sp. Flavobacteria sp., Alteromonas spp.,
Psedoalteromonas spp., Bacillus sp., and Hahella chejuensis spp. are known to produce extracellular algicidal substances (Kim et al. 2008). Most of them are able to secrete metabolic compounds and might be used as biological control agent in natural seawater (Fukami et al. 1992; Wang et al. 2005). C. polikrikoides was decomposed within 20 min after the addition of either dense $V$. parahaemolyticus culture or filtrate of the culture. Thus, $C$. polikrikoides may be killed by direct physical contact and/or potential extracellular substances. C. polykrikoides has a thin surface membrane, while A. carterae and G. impudicum have relatively thick surface membrane, so called amphiesmal vesicles (Fraga et al. 1995). Furthermore, P. minimum and P. micans have theca (Roberts et al. 1995). Thus, V. parahaemolyticus or its excreting materials may easily penetrate and kill $C$. polykrikoides cells, while it has difficulty in penetrating and killing the cells of the other dinoflagellates. V. parahaemolyticus may deter the outbreak of red tides dominated by $C$. polykrikoides and/or accelerate the decline of red tides. Differential harmful effects by $V$. parahaemolyticus on $C$. polykrikoides compared to the other dinoflagellates may cause predominance by the other dinoflagellates over $C$. polykrikoides.

Red tides dominated by $C$. polykrikoides have caused great losses in many countries (Gárate-Lizárraga et al. 2004; Kim et al. 2004; Kim et al. 2007; Richlen et al. 2010). For example, its red tides have caused losses of up to USD \$ 60 million per year in the Korean aquaculture industry (NFRDI 1998). Thus, diverse methods of controlling the outbreak and persistence of red tides dominated by $C$. polykrikoides and thereby reducing their economic impacts have been suggested (Jeong et al. 2002, 2008). Use of algicidal bacteria is one of the methods widely suggested (e.g. Imai et al. 1995). The bacterium Micrococcus sp. LG-5 and Psedomonas sp. LG-2 have also been reported to kill $C$. polikrikoides (Jeong et al. 2000; Lee et al. 2008). However, these bacteria also killed several other red tide dinoflagellates. Thus, V. parahaemolyticus can be the only effective algicidal bacterium against $C$. polikrikoides, and not the other red tide dinoflagellates (i.e. semi-species specific).

The bacterium Psedoalteromonas haloplanktis AFMB008041 has been known to kill P. minimum, while Micrococcus sp. LG-5 and Psedomonas sp. LG-2 kill P. micans (Jeong et al. 2000; Kim et al. 2009; Table 1). However, the bacterium Alteromonas sp. which killed Akashiwo sanguinea, C. polykrikoides, Gymnodinium catenatum, and Heterocapsa 

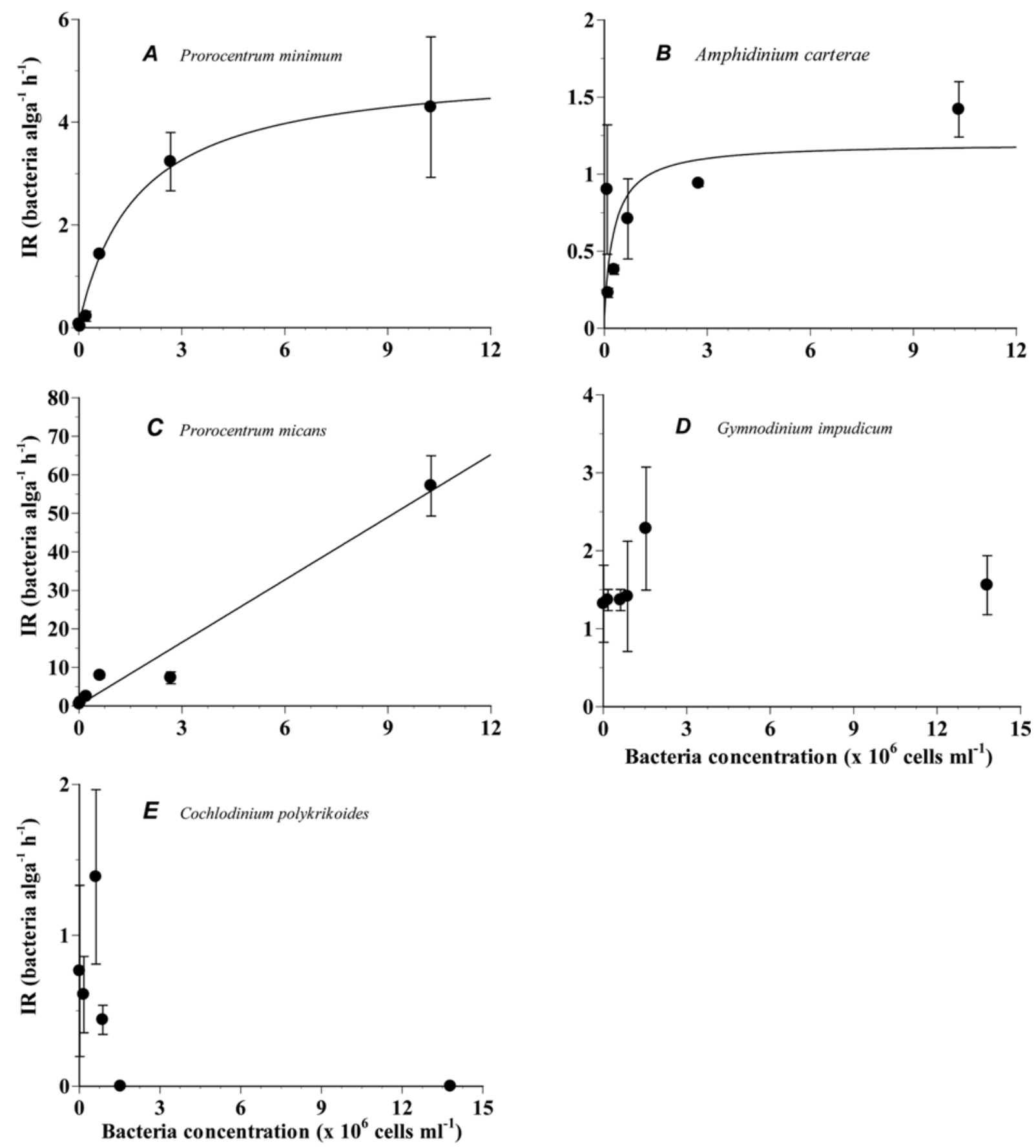

Fig. 8. Ingestion rate (cells alga $\mathrm{h}^{-1}$ ) of Prorocentrum minimum (A), Amphidinium carterae (B), P. micans (C), Gymnodinium impudicum (D), and C. polykrikoides(E) on Vibrio parahaemolyticus a function of the initial bacterial concentration $\left(\mathrm{x}\right.$, cells $\left.\mathrm{ml}^{-1}\right)$. Each ingestion rates was calculated by exploration from a linear regression curve on the number of prey cells inside a dinoflagellate predator cell over incubation time. Symbols represent treatment mean \pm 1 SE. The curves were fitted by a Michaelis-Menten equation (Eq 2) in (A) and (B) and a linear equation in (C) using all treatments in the experiment. Ingestion rate (IR, cells dinoflagellate $\left.^{-1} \mathrm{~h}^{-1}\right)=5.1[\mathrm{x} /(1,700,000+\mathrm{x})], \mathrm{r}^{2}=0.991$ in $(\mathrm{A}), \mathrm{IR}=1.2[\mathrm{x} /(270,000+\mathrm{x})], \mathrm{r}^{2}=0.435$ in $(\mathrm{B}), \mathrm{IR}=5.378 \mathrm{x}+0.319, \mathrm{r}^{2}=0.968$ in $(\mathrm{C})$

triquetra did not kill P. minimum and P. micans (Lee et al. 2008). Therefore, the impact of algicidal activities on red tide algae including $P$. minimum and $P$. micans is
Psedoalteromonas haloplanktis AFMB-008041, Micrococcus sp. LG-5, and Psedomonas sp. LG-2 > Alteromonas sp. $>V$. parahaemolyticus. 


\section{Vibrio parahaemolyticus as prey}

All red tide dinoflagellates tested in the present study were able to feed on $V$. parahaemolyticus. However, $C$. polikrikoides was not able to feed on this bacterium at bacterial concentrations of $\leq 1.5 \times 10^{6}$ cells $\mathrm{ml}^{-1}$ because the dinoflagellate was killed at this concentration.

The maximum ingestion rate of $P$. minimum on $V$. parahaemolyticus (5.1 cells alga ${ }^{-1} \mathrm{~h}^{-1}$ ) were considerably lower than that on mixed bacteria, which originally lived in dinoflagellate culture $\left(21.9\right.$ cells alga ${ }^{-1} \mathrm{~h}^{-1}$; Seong et al. 2006). Furthermore, the maximum ingestion rate of $C$. polikrikoides on $V$. parahaemolyticus ( 1.3 cells alga $\left.{ }^{-1} \mathrm{~h}^{-1}\right)$ was also much lower than that on mixed bacteria in Masan Bay (17.4 cells alga ${ }^{-1} \mathrm{~h}^{-1}$; Seong et al. 2006). The size of $V$. parahaemolyticus used in the present study was similar to that of bacteria used in Seong et al. (2006). Thus, for the red tide dinoflagellate predators, $V$. parahaemolyticus may not be as good prey as mixed bacteria used in Seong et al. (2006).

The growth rate of $P$. minimum at the $V$. parahaemolyticus concentration of $8.8 \times 10^{5}$ was significantly higher than that in the control. The daily acquired bacterial carbon by $P$. minimum from $V$. parahaemolyticus $[8.2 \mathrm{pg} \mathrm{C}(5.1 \times 24 \times$ $0.067 \mathrm{pgC})]$ was only $6.3 \%$ of the body carbon of $P$. minimum. Thus, $V$. parahaemolyticus cannot only support the positive growth of $P$. minimum. However, $V$. parahaemolyticus may stimulate or partially support the growth of P. minimum. Another bacterium, Alteromonas sp. strain A14, was known to stimulate the growth of $P$. minimum at the prey concentration of $\sim 10^{6}$ cell ml$~^{-1}$ (Lee et al. 2008).

In conclusion, $V$. parahaemolyticus can be killer and simultaneous prey for all red tide dinoflagellates tested in the present study; $V$. parahaemolyticus induces the most harmful effects on C. polykrikoies; Bacterial concentration and incubation time were important factors; With increasing $V$. parahaemolyticus concentration, ingestion rates of $P$. minimum, $P$. micans, and A. carterae on the prey increased, whereas ingestion rates on $C$. polykrikoides decreased.

\section{Acknowledgements}

This work was supported by the Korea Research Foundation Grant funded by the Korean Government (MOEHRD, Basic Research Promotion Fund) (KRF-2008-359-C00048).

\section{References}

Amaro AM, Fuentes MS, Ogalde SR, Venegas JA, Suarez BA (2005) Identification and characterization of potentially algal-lytic marine bacteria strongly associated with the toxic dinoflagella Alexandrium catenella. J Eukary Microb 52(3): 191-200

Andersen RJ, Wolfe MS, Faulkner DJ (1974) Autotoxic antibiotic production by a marine Chromobacterium. Mar Biol 27:281285

Azam F (1998) Microbial control of oceanic carbon flux: the plot thickens. Science 280:694-696

Bienfang PK, DeFelice SV, Laws EA, Brand LE, Bidigare RR, Christensen S, Trapido-Rosenthal H, Hemscheidt TK, McGillicuddy Jr DJ, Anderson DM, Solo-Gabriele HM, Boehm AB, Backer LC (2011) Prominent human health impacts from several marine microbes: history, ecology, and public health implications. Int J Microb 2011:152815. doi:10.1155/ 2011/152815

Byun HG, Jeong SY, Park YT, Lee WJ, Kim SK (2002) Algicidal activity of substance purified from marine bacteria metabolites against Cochlodinium polykrikoides. J Fish Sci Tech 5(3):150155

Dadisman TA Jr, Nelson R, Molenda JR, Garber HJ (1972) Vibrio parahaemolyticus gastroenteritis in Maryland I. Clinical and epidemiologic aspects. Am J Epidemiol 96(6):414-426

Doucette GJ, Kodama M, Franca S, Gallacher S (1998) Bacterial interactions with harmful algal bloom species: bloom ecology, toxigenesis, and cytology. In: Anderson DA, Cembella AD, Hallegraeff GM (eds) Physiological ecology of harmful algal blooms, Vol 41. Springer-Verlag, Heidelberg, pp 29-48

Doucette GJ, McGovern ER, Babinchak JA (1999) Algicidal bacteria active against Gymnodinium breve(Dinophyceae). I. Bacterial isolation and characterization of killing activity. J Phycol 35:1447-1457

Eiler A, Johansson M, Bertilsson S (2006) Environmental influences on Vibrio populations in Northern temperate and boreal coastal waters (Baltic and Skagerrak Seas) Appl Environ Microb 72(9):6004-6011

Fraga S, Bravo I, Delgado M, Franco JM, Zapata M (1995) Gyrodinium impudicum sp.nov.(Dinophyceae), a non toxic, chain-forming, red tide dinoflagellate. Phycologia 34(6):514521

Furusawa G, Yoshikawa T, Yasuda A, Sakata T (2003) Algicidal activity and gliding motility of Saprospira sp. SS98-5. Can J Microbiol 49:92-100

Fukami K, Yuzawa A, Nishijima T, Hata Y (1992) Isolation and properties of a bacterium inhibiting the growth of Gymnodinium nagasakiense. Nippon Suisan Gakkaishi 58(6):1073-1077

Gárate-Lizárraga I, López-Cortes DJ, Bustillos-Guzmán JJ, Hemández-Sandoval F (2004) Blooms Cochlodinium 
polykrikoides (Gymnodiniaceae) in the Gulf of California, Mexico. Rev Biol Trop 52(Suppl.1):51-58

Green DH, Llewllyn LE, Negri AP, Blackburn SI, Bolch CJ (2004) Phylogenetic and functional diversity of the cultivable bacterial community associated with the paralytic shellfish dinoflagellate Gymnodinium catenatum. FEMS Microbiol Ecol 47(3):345-357

Guillard RRL, Ryther JH (1962) Studies of marine planktonic diatoms. I. Cyclotella nana (Hustedt) and Detonula confervacea (Cleve). Can J Microbiol 8:229-239

Hackett JD, Anderson DM, Erdner DM, Bhattacharya D (2004) Dinoflagellates: a remarkable evolutionary experiment. Am J Bot 91:1523-1534

Hare CE, Demir E, Coyne KJ, Cary SC, Kirchman DL, Hutchins DA (2005) A bacterium that inhibits the growth of Pfiesteria piscicida and other dinoflagellates. Harmful algae 4:221-234

Hervio-Heath D, Colwell RR, Derrien A, Robert-Pillot A, Fournier JM, Pommepuy M (2002) Occurrence of pathogenic vibrios in coastal areas of France. J Appl microbiol 92(6):1123-1135

Holmstrom C, Kjelleberg S (1999) Marine Psedoalteromonas species are associated with higher organisms and produce biologically active extracellular agents. FEMS Microbiol Ecol 30:285-293

Imai I, Ishida Y, Hata Y (1993) Killing of marine phytoplankton by a gliding bacterium Cytophaga sp. isolated from the coastal sea of Japan. Mar Biol 116:527-532

Imai I, Ishida Y, Sakaguchi K, Hata Y (1995) Algicidal marine bacteria isolated from northern Hiroshima Bay, Japan. Fish Sci Tokyo 61(4):628-636

Imai I, Sunahara T, Nishikawa T, Hori Y, Kondo R, Hiroishi S (2001) Fluctuation of the red tide flagellates Chattonella spp. (Raphidophyceae) and the algicidal bacterium Cytophaga sp. in the Seto Inland Sea. Mar Biol 138:1043-1049

Imai I, Kimura S (2008) Resistance of the fish-killing dinoflagellate Cochlodinium polykrikoides against algicidal bacteria islolated from the coastal sea of Japan. Harmful algae 7:360-367

Jasti S, Sieracki ME, Poulton NJ, Giewat MW, Rooney-Varga JN (2005) Phylogenetic diversity and specificity of bacteria closely associated with Alexandrium spp. and other phytoplankton. Appl Environ Microbiol 71(7):3483-3494

Jeong SY, Park YT, Lee WJ (2000) Isolation of marine bacteria killing red tide microalgae. III: algicidal effects of marine bacterium, Micrococcus sp. LG-5 against the harmful dinoflagellate, Cochlodinium polykrikoides. J Korean Fish Soc 33(4):331-338

Jeong HJ, Kim HR, Kim KI, Kim KY, Park KH, Kim ST, Yoo YD, Song JY, Seong KA, Yih WH, Pae SJ, Lee CH, Huh $\mathrm{MD}$, Lee $\mathrm{SH}$ (2002) $\mathrm{NaOCl}$ produced by electrolysis of natural seawater as a potential method to control marine red tide dinoflagellates. Phycologia 45:643-656

Jeong HJ, Kim JS, Yoo YD, Kim ST, Song JY, Kim TH, Seong
KA, Kang NS, Kim MS, Kim JH, Kim S, Ryu J, Lee HM, Yih WH (2008) Control of the harmful alga Cochlodinium polykrikoides by the naked ciliate Strombidinopsis jeokjo in mesocosm enclosures. Harmful Algae 7:368-377

Kim MC, Yu HS, Ok MS, Kim CH, and Chang DS (1999) The activities and characteristics of algicidal bacteria in Chindong Bay. J Korean Fish Soc 32(3):359-367

Kim DI, Matsuyama Y, Mineo SN, Yoon YH, Oshima Y (2004) Effects of temperature, salinity and irradiance on the growth of the harmful red tide dinoflagellate Cochlodinium polykrikoides Margalef(Dinophyceae). J Plankton Res 26:61-66

Kim CJ, Kim HG, Kim CH, Oh HM (2007) Life cycle of the ichthyotoxic dinoflagellate Cochlodinium polykrikoides in Korean coastal waters. Harmful algae 6(1):104-111

Kim D, Kim JF, Yim JH, Kwon SK, Lee CH (2008) Red to redthe marine bacterium Hahella chejuensis and its product prodigiosin for mitigation of harmful algal blooms. J Microbiol Biotechnol 18(10):1621-1629

Kim JD, Kim JH, Park JK, Lee CG (2009) Selective control of the Prorocentrum minimum harmful algal blooms by a novel algal-Lytic bacterium Psedoalteromonas haloplanktis AFMB008041. Mar Biotechnol 11:463-472

Kitaguchi H, Hiragushi N, Mitsutani A, Yamaguchi M, Ishida Y (2001) Isolation of an algicidal marine bacterium with activity against the harmful dinoflagellate Heterocapsa circularisquama (Dinophyceae). Phycologia 40(3):275-279

Lee WJ, Kim HG, Park YT, Seong HI(1990) The role of marine bacteria in the dinoflagellate bloom. Bull Korean Fish Soc 23(4):303-309

Lee WJ, Park YT(1998) Isolation of marine bacteria killing red tide microalgae. II: isolation and algicidal properties of Psedomonas sp. LG-2 possessing killing activity for dinoflagellate, Prorocentrum micans. J Korean Fish Soc 31(6):852-858

Lee BK, Katano T, Kitamura SI, Oh MJ, Han MS (2008) Monitoring of algicidal bacterium, Alteromonas sp. Strain A14 in its application to natural Cochlodinium polykrikoides blooming seawater using fluorescence in situ hybridization. J Microbiol 46(3):274-282

Makino K, Oshima K, Kurokawa K, Yokoyama K, Uda T, Tagomori K, lijima Y, Najima M, Nakano M, Yamashita A, Kubota Y, Kimura S, Yasunaga T, Honda T, Shinagawa H, Hattori M, lida T (2003) Genome sequence of Vibrio parahaemolyticus: a pathogenic mechanism distinct from that of $V$. cholera. The Lancet 361(9359):743-749

Manage PM, Kawabata Z, Nakano SI (2000) Algicidal effect of the bacterium Alcaligenes denirificans on Microcystis spp. Aquat Microb Ecol 22(2):111-117

Mayali X, Azam F(2004) Algicidal bacteria in the sea and their impact on algal blooms. J Eukaryot Microbiol 5(2):139-144

Nakashima T, Kim D, Miyazaki Y, Yamaguchi K, Takeshita S, Oda T (2006) Mode of action of an antialgal agent produced 
by a marine gamma Proteobacterium against Chattonella marina. Aquat Microb Ecol 45:255-262

National Fisheries Research and Development Institute (NFRDI) (1998) Red tides in Korea. National Fisheries Research \& Development Institute, Korea, 292 p

Nayak BB, Karunasagar I, Karunasagar I (2000) The survival of different Vibrios in association with a laboratory culture of the red-tide-causing organism Amphidinium carterae. World J Microbiol Biotechnol 16:99-101

Nygaard K, Tobiesen A (1993) Bacterivory in algae: a survival strategy during nutrient limitation. Limnol Oceanogr 38:273-279

Park YT, Park JB, Chung SY, Song BC, Lim WA, Kim CH, Lee WJ (1998) Isolation of marine bacteria killing red tide microalgae. I. Isolation and algicidal properties of Micrococcus sp. LG-1 possessing killing activity for harmful dinoflagellate, Cochlodinium polykrikoides. J Korean Fish Soc 31(5):767773

Richlen MM, Morton SL, Jamali EA, Rajan A, Anderson DM (2010) The catastrophic 2008-2009 red tide in the Arabian gulf region, with observations on the identification and phylogeny of the fish-killing dinoflagellate Cochlodinium polykrikoides. Harmful algae 9:163-172

Roberts KR, Heimann K, Wetherbee R (1995) The flagellar apparatus and canal structure in Prorocentrum micans (Dinophyceae). Phycologia 34(4):313-322
Romalde JL, Torazo AE, Barja JL (1990) Changes in bacterial populations during red tides caused by Mesodinium rubrum and Gymnodinium catenatum in North-West coast of Spain. J Appl Bacteriol 68:123-132

Seong KA, Jeong HJ, Kim S, Kim GH, Kang JH (2006) Bacterivory by co-occurring red-tide algae, heterotrophic nanoflagellates, and ciliates on marine bacteria. Mar Eco Prog Ser 322:85-97

Sherr EB, Sherr EB, Fallon RD (1987) Use of monodispersed, fluorescently labeled bacteria to estimate in situ protozoan bacterivory. Appl Environ Microb 53(5):958-965

Skerratt JH, Bowman JP, Hallegraeff G, James S, Nichols PD (2002) Algicidal bacteria associated with blooms of a toxic dinoflagellate in a temperate Austalian estuary. Mar Ecol Prog Ser 244:1-15

Wang X, Gong L, Liang S, Han X, Zhu C, Li Y (2005) Algicidal activity of rhamnolipid biosurfactants produced by Psedomonas aeruginosa. Harmful algae 4:433-443

Wright AC, Shneider RG, Hubbard MA, Schneider KR (2009) Preventing foodborne and non-foodborne illness: Vibrio parahaemolyticus. University of Florida IFAS Extention FSHN09-01

Yeung PS, Boor KJ (2004) Epidemiology, pathogenesis, and prevention of foodborn Vibrio parahaemolyticus infections. Foodborne Pathog Dis 1(2):74-88 